\title{
CEREBRAL EQUINE HYDATIDOSIS IN SOUTHERN BRAZIL
}

\author{
HIDATIDOSE CEREBRAL EM EQÜINO NO SUL DO BRASIL
}

\author{
Jerônimo Lopes Ruas ${ }^{1}$ Ana Lucia Schild ${ }^{1}$ Cristina Gevehr Fernande ${ }^{2}$ \\ João Luiz Montiel Ferreira ${ }^{1}$ Gertrud Müller $^{3}$
}

\section{- CASE REPORT -}

\section{SUMMARY}

Equine cerebral hydatid disease is described in a 7-year-old, crossbred, female horse. Clinical signs were characterized by circling gait, pressing of head against fences or objects and motor incoordination. On gross examination of the brain the hemispheres were swollen, mainly the left one. On transversal sections, a $5 \mathrm{~cm} \times 7 \mathrm{~cm}$ fluid-filled cyst was observed within the lateral ventricle of the left hemisphere. The cyst extended from the parietal to the occipital lobe, and compressed the third ventricle. There was also marked mid line deviation. Histologically, the brain lesion adjacent to the cyst, was characterized by a piogranulomatous process and vacuolization of neuropil. A diagnosis of equine hydatidosis caused by Echinococcus granulosus was made on the basis of the morphometric features of protoscolices hooks.

Key words: hydatid disease, horse, Echinococcus granulosus. RESUMO

Descreve-se um caso de hidatidose cerebral em um eqüino, cruza, fêmea, de 7 anos de idade, que apresentou sinais clínicos nervosos de torneio, pressão da cabeça contra cercas e objetos e incoordenação motora. Na abertura da caixa craniana observou-se aumento de volume do cérebro, mais acentuado no hemisfério esquerdo. Ao corte observou-se, no interior do ventrículo lateral esquerdo, um cisto de aproximadamente $5 \mathrm{~cm} \times 7 \mathrm{~cm}$, de parede branca opaca, com conteúdo líquido translúcido, que se estendia desde o lobo parietal até o lobo ocipital, comprimindo o tecido nervoso. No exame histológico do cérebro observou-se, na área contígua à parede do cisto a presença de um processo inflamatório piogranulomatoso e vacuolização da neurópila. Os dados morfométricos do cisto, dos protoescóleces e dos ganchos permitiram concluir que o cisto era de Echinococcus granulosus.

Palavras-chave: cisto hidático, equino, Echinococcus granulosus

\section{INTRODUCTION}

Hydatid disease is a zoonosis caused by infection with a metacestode belonging to the genus Echinococcus. The disease is characterized by cysts containing numerous thin protoscolices that most often develop in the liver and lungs. It may develop also in the kidney, spleen, nervous tissue, or bone of intermediate hosts (BARNETT et al., 1988;

\footnotetext{
${ }^{1}$ Médicos Veterinários - Laboratório Regional de Diagnóstico (LRD), Faculdade de Veterinária - UFPel, Campus Universitário s/nº 96010 900 - Pelotas, RS. Corresponding author.

${ }^{2}$ Professor Assistente do Departamento de Patologia - Faculdade de Veterinária - UFPel.

${ }^{3}$ Professor Assistente do Instituto de Biologia - UFPel.
} 
BINHAZIM et al., 1992). Sheep appear to be the most common intermediate host in most areas of the world, but in some regions other domestic ungulates, including goats, cattle, swine, buffalo, horses, and camels serve as hosts (BRYAN \& SCHANTZ, 1989). Human beings may serve as accidental intermediate hosts (BINHAZIM et al., 1992) and can be infected by all species of the genus Echinococcus (ECKERT \& THOMPSON, 1994). After ingestion of the hexacanth by the intermediate host, the larva escapes from the egg, penetrates the intestinal mucosa and migrates via lymphatic and blood vessels to distant sites. At these sites the larva develops into a metacestode, forming a hydatid cyst that grows and produces numerous protoscolices. Clinical signs depend on cyst size and location (BRYAN \& SCHANTZ, 1989). After ingestion by a carnivore, protoscolices develop into adult tape worms in its intestines (BINHAZIM et al., 1992).

Four species of Echinococcus are recognized: E. granulosus, E. multilocularis, $\boldsymbol{E}$. oligarthrus and $\boldsymbol{E}$. vogeli. The first one has been found on all continents except Antarctica (BRYAN \& SCHANTZ, 1989). A great many intraspecific variants or strains of Echinococcus have been described from different geographic areas or in different intermediate host species (THOMPSON \& LYMBERY, 1990).

The sheep strain of the E. granulosus is observed in all continents. In South America it causes economic losses and problems for public health. It occurs in Argentina, Chile, Uruguay, some regions of Peru, Bolivia, and Brazil, particularly in the Rio Grande do Sul state (SCHANTZ, 1994). In these endemic areas, the prevalence of ovine hydatid cysts varies between $35 \%$ to $50 \%$. The hydatid cyst has also high prevalence in goats, cattle and swine in these countries (SCHANTZ, 1994).

The equine strain of $\boldsymbol{E}$. granulosus has large distribution in the United Kingdom, and also occurs in Switzerland, Belgium, Italy, Syria and South Africa (THOMPSON \& LYMBERY, 1990). In Great Britain hydatid disease is often observed in horses. EDWARDS (1982) observed that prevalence of infection was closely related to age, rising from nil in animals up to two years of age to over $20 \%$ of those over 8 years. THOMPSON \& SMYTH (1975) observed prevalence rates ranging from $35 \%$ to $60 \%$. Surveys in the United Kingdom have reported that prevalence of hydatid infection is higher in horses used for hunting, because they graze on pasture frequented by foxhounds and other infected dogs. In Ireland, the prevalence of infected horses, at slaughterhouses, varies between $10 \%$ to $62 \%$ (BINHAZIM et al.,
1992). In these countries the disease has been correlated with the common practice of feeding dogs raw or improperly cooked offal from horses (BINHAZIM et al., 1992).

Equine hydatid disease is apparently rare in North America and there are only 5 reports of $\boldsymbol{E}$. granulosus infection in imported horses from Ireland or United Kingdom and one record of autochthonous echinococosis in an equine host of North American origin (HOBERG et al., 1994). Equine hydatid disease has not been described in Brazil.

\section{CASE REPORT}

A 7-year-old, crossbred, female equine from Piratini county, showed neurological signs characterized by balance of the head during gait. After 3 days from the onset of signs the horse showed a circling gait and pressed its head against fences or objects. On the $4^{\text {th }}$ day the equine showed severe motor incoordination followed by permanent lateral recumbence. On the $10^{\text {th }}$ day it died and was necropsied. The animal had been fed with corn and natural grass. It was introduced at the farm approximately one year before the observation of clinical signs. The Veterinarian suspected of leukoencephalomalacia and sent the horse's head and the feeding corn to the Diagnostic Laboratory.

On gross examination of the CNS, the cerebellum was herniated through the foramen magnum. The hemispheres, mainly the left one, were swollen with flattened gyri. On transversal sections, a $5 \mathrm{~cm} \times 7 \mathrm{~cm}$ fluid-filled cyst was observed within the lateral ventricle of the left hemisphere. The cyst extended from the parietal to the occipital lobe, and compressed the third ventricle. There was also marked mid line deviation (Figure 1).

Histologically, the cyst wall was surrounded by pus and granulation tissue occasionally infiltrated by macrophages, epithelioid cells, giant cells, neutrophils and eosinophils. The ependymal epithelium was disrupted and ependymal cells were found within the pus or adjacent to the granulation tissue. Spongiosis and presence of few gitter cells were observed in the neuropil adjacent to the lesion.

The cyst had a thick opaque wall and contained clear fluid with numerous protoscolices free or inside a broad capsule. The protoscolices had $160 \mu \mathrm{m}$ X $120 \mu \mathrm{m}$ of length (Figure 2). Rostellar armature consisted of 28-40 hooks (Figure 3).

The length of large hooks ranged between 22 to $44 \mu \mathrm{m}$ and the length of small hooks ranged between 18 to $22 \mu \mathrm{m}$. 
The diagnosisof equine hydatidosis caused by Echinococcus granulosus was made on the basis of the morphometric features of protoscolices hooks.

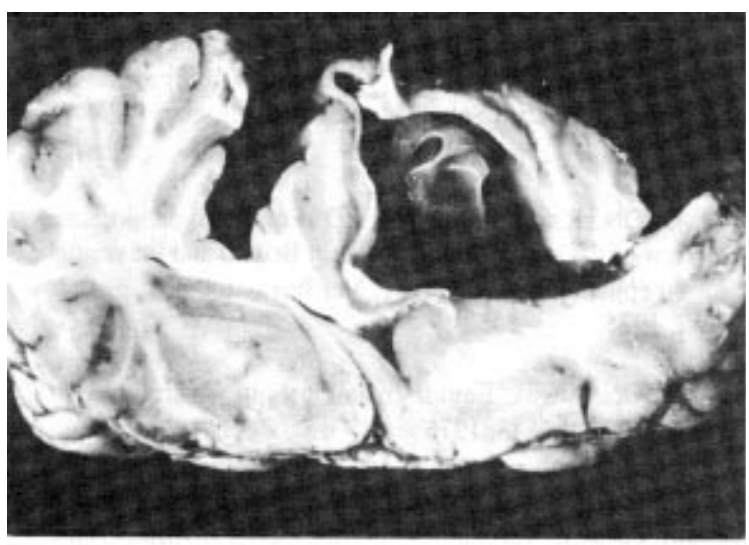

'igure 1 - Transversal section of the brain showing the Echinococcus gramulosus cyst within the lateral ventricle. There is compression of the $3^{\text {nt }}$ ventricle and deviation of the mid line.

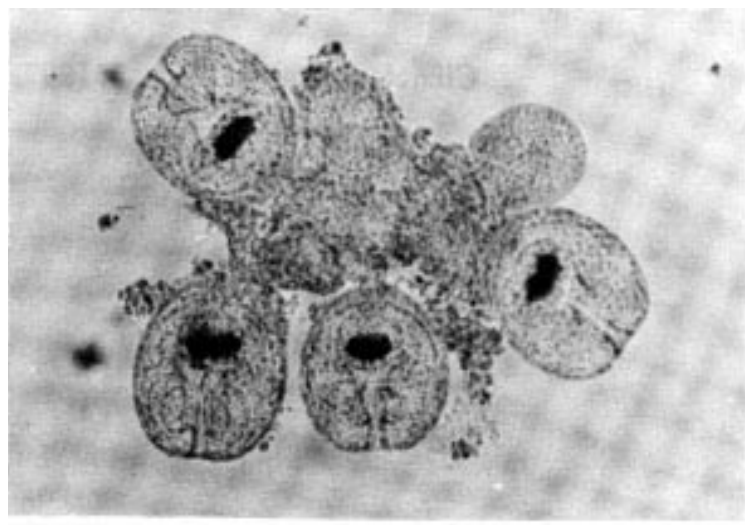

Figure 2 - Microscopical aspect of the cyst protoscolices $(100 \mathrm{X})$.

\section{DISCUSSION}

Morphometric features of protoscolices hooks observed in this case of equine hydatid disease are similar to those described by THOMPSON \& LYMBERY (1988).

Clinical signs observed in this case were due to the location of the cyst in the CNS. Hydatid cysts are common incidental post-mortem findings in horses in the United Kingdom, being found most frequently in the liver and lungs. However, hydatid cysts are well tolerated by horses and clinical hydatidosis is rare, even in heavily infected animals (McGORUM et al., 1994).

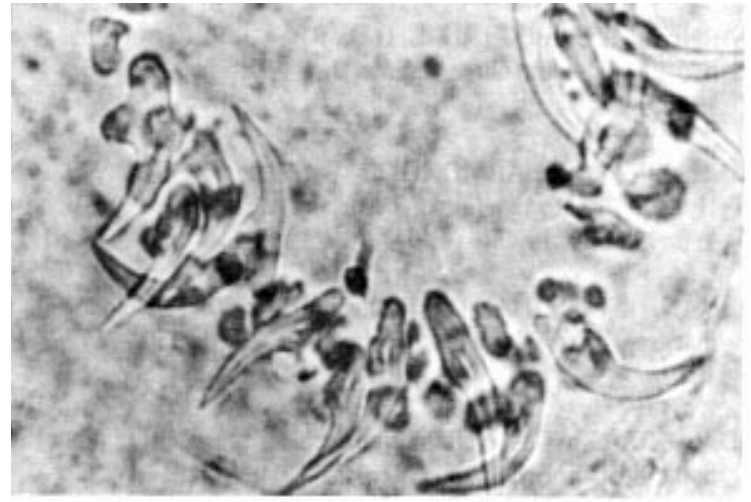

Figure 3 - Microscopical aspect of the large and small protoscolices hooks $(200 \mathrm{X})$.

There are evidences that the sheep strain of Echinococcus granulosus does not affect horses, and the equine strain does not affect sheep (BINHAZIM et al., 1992). Some limited cross infection experiments carried out in these species suggested that horses are resistant to infection by $\boldsymbol{E}$. granulosus of sheep origin, whereas sheep may support limited development of the horse form (THOMPSON \& LYMBERY, 1988). Furthermore, hydatid cysts are often observed in sheep and cattle but not in horses in Rio Grande do Sul state. In some countries where the disease is common in sheep, like New Zealand, horses are not infected. In others, like Republic of Ireland where the disease is common in horses, sheep are not infected (THOMPSON \& SMYTH, 1975). These features suggest that the equine hydatid disease reported here was due to the equine strain which has not been previously reported in the country.

The epidemiological data from this case does not allow to establish the infection source. The horse was introduced in the farm about 1 year before clinical illness and probably it was infected before that time. HOBERG et al. (1994) reported a case of autochthonous equine echinococcosis in North America. They related it to the importation of hunting dogs with this cestode from the United Kingdom. Some of traditional hunting establishments in North America have the practice of feeding hounds with raw viscera and meat from horses (HOBERG et al., 1994). In Southern Brazil importation of hunting dogs are not a common practice, and it would appear that this source of infection is improbable in this case.

The present case may be epidemiologically significant and it is necessary an accurate investigation, mainly at equine slaughterhouses, to determine the incidence and patterns of transmission among horses in Southern Brazil.

Ciência Rural, v. 27, n. 2, 1997. 


\section{REFERENCES}

BARNETT, K.C., COTTRELL, B.D., REST. J.R. Retrobulbar hydatid cyst in the horse. Eq Vet J, v. 20, n. 2, p. 136-138, 1988.

BINHAZIM, A.A., HARMON, B.G., ROBERSON, E.L., et al. Hydatid disease in a horse. J Am Vet Med Ass, v. 200, n. 7, p. 958-960, 1992.

BRYAN, R.T., SCHANTZ, P.M. Equinococcosis (hydatid disease). J Am Vet Med Ass, v. 195, n. 9, p. 1214-1217, 1989.

EDWARDS, G.T. Observations on the epidemiology of equine hydatidosis in Britain. Vet Rec, n. 110, p. 511-514, 1982.

ECKERT, J., THOMPSON, R.C.A. Características biológicas y variación entre cepas de Echinococcus Reunión del grupo científico de trabajo sobre los adelantos en la prevención, el control y el tratamiento de la Hydatidosis. Organización Panamericana de la Salud. Montevideo, Uruguay 1994. p. 1-18.

HOBERG, E.P., MILlER, S., BROWN, M.A. Equinococcus granulosus (Taeniidae) and autochthonous echinococcosis in a north american horse. J Parasitol, v. 80, n. 1, p. 141-144, 1994.
McGORUM, B.C., RAILTON, D.I., CLARKE, C.J., $\boldsymbol{e} \boldsymbol{t} \boldsymbol{a l}$. Pleuropneumonia associated with pulmonary hydatidosis in a horse. Eq Vet J, v. 26, n. 3, p. 249-250, 1994.

SCHANTZ, P.M. Características epidemiológicas da la echinococosis quística: distribuición y modalidades de transmisión en el mundo. Reunión del grupo científico de trabajo sobre los adelantos en la prevención, el control y el tratamiento de la Hydatidosis. Organización Panamericana de la Salud. Montevideo, Uruguay 1994. p. 2644.

THOMPSON, R.C.A., SMYTH, J.D. Equine hydatidosis: a review of the current status in Great Britain and the results of an epidemiological survey. Vet Parasitol, n. 1, p. 107$127,1975$.

THOMPSON, R.C.A. Equine hydatidosis in Australia. Aust Vet J, v. 52, p. 543, 1976.

THOMPSON, R.C.A., LYMBERY, A.J. The Nature, extent and significance of variation within the genus Echinococcus: Adv Parasitol, v. 27, p. 210-258, 1988.

THOMPSON, R.C.A., LYMBERY, A.J. Echinococcus: biology and strain variation. Intern J Parasitol, v. 20. n. 4, p. 457470, 1990 